\title{
Proceeding
}

Supplementary Issue: Summer Conferences of Sports Science. Costa Blanca Sports Science Events, 20-21 September 2019. Alicante, Spain.

\section{Studying tennis theory, methodology and didactics: Laboratory didactics experiments for motor sciences}

\author{
DIEGO DAVIDE ${ }^{1}$, ROBERTA ROSA², DOMENICO TAFURI ${ }^{1}$ \\ ${ }^{1}$ Parthenope University, Naples, Italy \\ 2IUL Telematic University, Italy
}

\begin{abstract}
Can a literary success become the starting point for a course on individual sports methodologies? The didactic experiment described in these pages shows that reading and sports are not in antithesis, but they can work together to develop innovative didactic methods that keep up with the attitudes and needs of the digital natives generation. Keywords: Tennis; Laboratory didactics experiments; Motor sciences; Learning.

\section{Cite this article as:}

Davide, D., Rosa, R., \& Tafuri, D. (2019). Studying tennis theory, methodology and didactics: Laboratory didactics experiments for motor sciences. Journal of Human Sport and Exercise, 14(5proc), S1938S1943. doi:https://doi.org/10.14198/jhse.2019.14.Proc5.13
\end{abstract}

Corresponding author. Parthenope University, Naples, Italy.

E-mail: domenico.tafuri@uniparthenope.it

Supplementary Issue: Summer Conferences of Sports Science. Costa Blanca Sports Science Events, 20-21 September 2019. Alicante, Spain.

JOURNAL OF HUMAN SPORT \& EXERCISE ISSN 1988-5202

(c) Faculty of Education. University of Alicante doi:10.14198/jhse.2019.14.Proc5.13 


\section{INTRODUCTION}

The advent of information technology, a student audience made up of digital natives and a new idea of teaching purposes and methods, makes it necessary to renew didactics in all disciplinary fields.

In particular, the scholars' reflections focused on the need to keep together knowledge and skills, intended as indispensable attributes in the training of students, in the organization of didactic paths, and in the planning and development of curricula. It was therefore argued that it is appropriate to give life to a training course that organizes, according to a hierarchical principle, the knowledge and skills connected to it, and that a framework of further competences has to be built on this. In this type of didactics, the laboratory and laboratory didactics are essential moments as they allow for a wide socialization of the work, opening the way to a collaborative relationship with the students and all the teachers involved.

The laboratory activity set out in this essay describes the work carried out with the chair of Individual Sports TMD, in collaboration with the chair of Pedagogy and Psychology, starting from the biography of one of the greatest tennis players of our time: André Agassi. The goal was to learn the rules, techniques, training methods and organization of the discipline of Tennis ${ }^{1}$, through the critical analysis of a literary text ${ }^{2}$ that sold more than 370 thousand copies and enjoyed success even among those who never gripped a racket their lives.

\section{LABORATORY ORGANIZATION: THE CHOICE OF THE LITERARY TEXT}

The most significant moment of the organizational phase of the laboratory was choosing the text to be analysed. In this case, leaving aside the strictly literary aspect, it was decided to delimit the choice of novels or memoirs which had, as their protagonists, sportsmen of recognized fame, and which would allow deepening more key themes: sports performance, psychological aspects, clinical aspects, virtuous training models, mentality, reference cultural models, sport and social unease. It seemed to us that this density of arguments was in the book "Open. La mia storia.", published in Italy by Einaudi Editor in 2011, and dedicated to the career of the American tennis player André Agassi, a professional who worked in the two decades from 1986 to 2006: number one for many years in the world rankings, winner of eight Grand Slam and Golden Slam tournaments. Agassi has won 60 ATP titles, eight Slam tournaments, a Golden Slam and is still considered one of the greatest tennis players of all time. As a professional, he managed to get more than $\$$ 31 million in prizes, and $\$ 150$ million in sponsorships.

The novel, which is largely autobiographical, talks about the career of the player born in Nevada starting from the very first times in his house backyard, where his father, an ex-boxer of Iranian origins, obliged him to chase the balls thrown by a machine he nicknamed "the Dragon", to the point of exhaustion ${ }^{3}$. He then entered the Nick Bollettieri Academy ${ }^{4}$ which he defined "a dignified prison camp" and where his rebellious character took over; he started drinking, smoking weed, cut his hair in Mohican style and experienced all kinds of extravagance. Agassi soon became aware of his talent and, although intimately torn between the desire for rebellion and that of always being impeccable, in 1986, when he was just sixteen, ended the season reaching the number 91 position in the world rankings. In the following year he reached number 25 position and, in

\footnotetext{
1 V. Santini, Tennis: gioco e didattica, Edi-ermes Editor, Milan, 2000.

2 D.Dalola and MT Rabitti, La Storia oltre i manuali. Come usare testi storiografici e testi di finzione storica, Mnamon Editor, Milan, 2017, pp. 11-19.

${ }^{3}$ M. Agassi and D. Colbello, Indoor: la nostra storia, Piemme Editor, Milan 2015.

${ }^{4}$ N. Bollettieri, Tennis, Siad Editor, Milan, 1986.
} 
1988, he even managed to enter the top 10. It was precisely in that year that his figure of rebel character consolidated, which led him to get many fans. His live appearances were characterized by the use of uniforms with bright colours and earrings, and constantly kept his long hair loose. In addition to sports questions, not without repercussions on the competitive life of the champion were the marriage and separation from the actress Brooke Shields; a period that coincided with the most negative moment of his sports career. Then it came the meeting with the women tennis champion Steffi Graf, and his rebirth as a tennis player, when many thought his career was over ${ }^{5}$. Steffi became his second wife and mother of his children, Jaden Gil and Jaz Elle. The book also talks about the commitment to the others and the birth of the Agassi Foundation, which deals with bringing sport and education into situations of social unease.

Retired from tennis, Agassi is still today an icon of this sport. A figure with strong personality, an unconventional player. For a matter of provocation, he would also put red polish on his nail and wear short jeans when playing, and this "over the top" personality made him gain millions of fans around the world.

\section{PRESENTATION TO LEARNERS AND START-UP OF THE LABORATORY}

The concept of "laboratory" itself, as a place of observation and experience, rejects the idea of a passive student with respect to the learning process, and requires continuous interaction with the teacher and the colleagues. Therefore, in the start-up phase, it is not possible to disregard the comparison, with the participants, on the contents and purposes of the activity, illustrating the genesis of the idea and underlining how active participation and teamwork are not only desirable, but essential for the success of the didactic experiment ${ }^{6}$. In order to take advantage of the possibilities offered by the network and the digital world ${ }^{7}$, thanks to the possibilities offered by social networks, it is desirable to create "groups", open to the participation of students and teachers, as further places for discussion, comparison and exchange of didactic materials ${ }^{8}$.

In the experience described in these pages, this preliminary phase was followed by that generic approach to the text, developed in two moments:

1. A short synopsis of André Agassi's book entitled Open;

2. Audio-visual sources found on the YouTube channel.

This allowed making a first contextualization of the literary text in the socio-cultural and sports horizon of that time and starting a brainstorming phase with the collection of impressions and information generated by the audio-visual sources ${ }^{9}$ watched. The debate revealed some broad issues:

$\checkmark \quad$ Parent-child relationship dynamics in relation to sports practice: coach parent, fan parent, parent seeking personal redemption;

$\checkmark \quad$ Sports performance and school performance: an often-controversial relationship;

\footnotetext{
${ }^{5}$ Brad Gilbert became Andre Agassi's coach and, in one year and a half, he brought him back to being world number one. B. Gilbert and S. Jamison, Vincere sporco: guerra mentale nel tennis: lezioni da un maestro Scarmagno, Priuli e Verlucca Editor, Turin, 2013.

${ }^{6}$ C. Brigadeci, A.Criscione, G.Deiana, G. Pennacchietti, Il laboratorio di storia. Problemi e strategie per l'insegnamento nella prospettiva dei nuovi curricoli e dell'autonomia didattica, Unicopli Editor, Milan, 2001.

${ }^{7}$ W.Panciera, E. Valseriati, La didattica della storia in Italia e in Europa. Un'introduzione, in E. Valseriati, Prospettive per la didattica, cit., p.11.

8 A. Gavosto, Un insegnamento più europeo passa per il lavoro di gruppo, La stampa, 19/12/2017. https://www.fondazioneagnelli.it/2017/12/19/un-insegnamento-piu-europeo-passa-lavoro-gruppo/ [consulted on 12.04.2019]. ${ }_{9}^{9}$ R. Ceserani, Guida allo studio della letteratura, Laterza Editor, Rome-Bari, 1999, pp. 204-220 and 575-576. 
$\checkmark \quad$ The act of rebellion and the infringement of the rules, on and off the field, as a request to be listened to;

$\checkmark \quad$ family balance and achievement of results;

$\checkmark \quad$ Sport as a means of emancipation and redemption;

$\checkmark \quad$ Physical trauma and psychological trauma;

$\checkmark \quad$ Sport before and after social media.

These topics were developed and in-depth analysed by the participants themselves during subsequent meetings, in which they were asked to hold dialogical-frontal lessons, carried out with the flipped classroom method. Thanks to the didactic materials shared by the teacher in the virtual classroom, the students had the opportunity to study the lesson at home, before the weekly meeting in the classroom. This type of approach allows the teacher optimizing the time spent in the classroom and grants the student the possibility to learn with the most suitable rhythm and supports to his learning style. ${ }^{10}$

These aimed at providing the historical sports coordinates necessary to frame the novel, and were followed by those developed personally by the teaching staff, which dealt with more strictly methodological questions relating to the game of tennis: rules, international tournaments, ATP rankings, scores, and great tennis players of yesterday and today. In view of an interdisciplinary work that would allow broadening the discussion to other area specialists, the teachers of psychology and pedagogy held specific lessons on the mental aspect of sports performance, and on the "healthy" way of doing sport for and with children and adolescents.

\section{MARGINAL CONSIDERATIONS ON THE EXPERIENCE}

In the laboratorial experience presented, the novel was used not as an alternative to specialized texts, but as an icebreaker to make the study of tennis TMDs enjoyable also by students who had never practiced this discipline, and who did not feel any kind of passion for it.

The critical use of Open prompted students to go beyond the playful reading, in order to activate their own ability of investigation, in-depth study and experimentation with didactic methods that can also be used in first and second grade schools.

In fact, the reading of the novel and its analysis was followed by the creation of a work - in laboratorial jargon called the "product" - which also aimed at breaking the short circuit that conceives reading as a mere pastime, distant and not very functional therefore from a process of intellectual and sports growth. Instead, in our case, literature has turned into "training": the student, in fact, while trying to distinguish between purposes and communication codes, develops a learning strategy, specifically the laboratory-type one, in which the practical effect of the knowledge building process is experienced. In this case, each student wrote an appendix to the text, in which each developed, analysed and documented some of the questions raised by the tennis player's story.

A laboratory-type approach reveals an effectiveness also from other points of view. It is believed that:

$\checkmark \quad$ It creates a space for meeting and interaction between the typical cultural horizon of millennials (of visual, musical, multimedia type), and didactics that meets their needs. Teaching and

10 F. Ozdamly, G. Asiksoy, Flipped classroom approach in World Journal of Educational Technology: Current Issues, vol.8, Issue 2, 2016, pp.98-105. 
learning take place through traditional manuals, but also through the contents made available by the internet and the multimedia;

$\checkmark \quad$ It put learners in a position to learn according to their own style, rhythm and modalities that are most suitable to them ${ }^{11}$;

$\checkmark \quad$ It provides an example of interdisciplinary didactics;

$\checkmark \quad$ It follows the path indicated by the European legislator, whereby it stimulates the development of those key competences to combine theoretical knowledge with the ability to implement them (the famous action learning) ${ }^{12}$.

$\checkmark \quad$ Laboratory didactics joins the emotional and evocative dimension to the scientific methodological one.

In the experience described above, the internet allowed changing the field of work and moving to the most suitable ground for young people, and thanks to the creation of a virtual classroom, it allowed keeping the debate on for an extended time, which went well beyond the hours set by the academic calendar. We can also state that we have recovered, for educational purposes, the actions that make up the daily interaction between millennials: video uploads, sound clips and sharing of various types of links. The teaching staff supervised the sharing of documents, so that, for each source, the origin and reliability were constantly verified, turning the moment of network research into a critical exercise. The methodology chosen provided participants with a new awareness, i.e. that learning is not only possible by reading the pages of the manual, but it is made up of documents and testimonies that must be compared, evaluated and verified. This same practice activates an inner process of gratification and confidence in the students' ability of discerning the topics under investigation.

Concerning the choice to use the memoir as the starting and destination point of the laboratory path, it is worth pointing out how functional it was to ignite the students' curiosity on issues that, within the narrative, became events and characters capable of capturing attention and arousing emotions (something that the manuals would certainly not have been able to do ${ }^{13}$ ). Beware, however, that "Open" was not the substitute for a methodology or psychology book, but a tool for reflection and work, thanks to which the student was able to concretely elaborate the knowledge acquired. What we have described, however, is only one of the many possibilities of carrying out participatory and cooperative training, which takes into account the change that school, university and society are experiencing today. There are currently many examples of history laboratories aimed at writing graphic novels or web games, rewriting or writing for the first time encyclopaedic entries for Wikipedia, in addition to many possible approaches to the innovation of didactics. ${ }^{14} \mathrm{For}$ this reason, each laboratory represents not only the experience of the moment, but also the place in which to store the result of one's own research, so that it is acquired and adapted also to other contexts and other needs.

\footnotetext{
${ }^{11} \mathrm{On}$ the different aptitudes of the students and the different ways of learning, see the essential work by $\mathrm{H}$. Gardner, Multiple intelligences. Dalla teoria alla prassi pedagogica, it.transl. by I. Blum, Milan, Anabasi Editor, 1994. Many hints are also recent W. McKenzie, Intelligenze multiple e tecnologie per la didattica: strategie e materiali per diversificare le proposte di insegnamento, Erickson Editor, Trento, 2006 R. Corallo, Nove volte intelligenti: attività per sviluppare le intelligenze multiple, Erickson Editor, Trento, 2011 e.

12 Recommendation of the European Parliament n. 962 dated December 18, 2006.

13 I. Mattozzi, Apprendere e far apprendere con testi storiografici e con le opere artistiche a sfondo storico, in D.Dalola and M.T. Rabitti, La Storia oltre i manuali, cit., Pp. 99-101.

${ }^{14} \mathrm{C}$.Bonelli and V.Caponetti, Che storia è questa, cit., pp. 59-72.
} 


\section{REFERENCES}

Agassi M. and Colbello D., Indoor: la nostra storia, Piemme Editor, Milan 2015.

Bollettieri N., Tennis, Siad Editor, Milan, 1986.

Brigadeci C., Criscione A., Deiana G., Pennacchietti G., II laboratorio di storia. Problemi e strategie per l'insegnamento nella prospettiva dei nuovi curricoli e dell'autonomia didattica, Unicopli Editor, Milan, 2001.

Ceserani R., Guida allo studio della letteratura, Laterza Editor, Rome-Bari, 1999.

Colombi V., Greppi C., Manera E., Olmoti G., Roda R., I linguaggi della contemporaneità. Una didattica digitale per la storia, Bologna 2018.

Corallo C., Nove volte intelligenti: attività per sviluppare le intelligenze multiple, Erickson Editor, Trento, 2011.

Dalola D. and Rabitti M.T., La Storia oltre i manuali. Come usare testi storiografici e testi di finzione storica, Mnamon Edito, Milan, 2017.

Gardner H., L'educazione delle intelligenze multiple. Dalla teoria alla prassi pedagogica, it. Transl. by I. Blum, Milan, Anabasi Editor, 1994.

Gilbert B. and Jamison S., Vincere sporco: guerra mentale nel tennis: lezioni da un maestro Scarmagno, Priuli e Verlucca Editor, Turin, 2013.

Lotti P. and Monari E., Come usare testi storiografici e testi di finzione storica, Milano, 2017.

Mc Kenzie W., Intelligenze multiple e tecnologie per la didattica: strategie e materiali per diversificare le proposte di insegnamento, Erickson Editor, Trento, 2006.

Ozdamly F., Asiksoy G., Flipped classroom approach in World Journal of Educational Technology: Current Issues, vol.8, Issue 2, 2016. 